\begin{tabular}{rr} 
çağdaş & Yaratıcı Drama Dergisi 2015, 10(2), 155-164 \\
drama & www.yader.org \\
\hline
\end{tabular}

\title{
Drama ve Oyunlaştırılmış Kısa Filmler Aracılığıyla Öğrenci Kişilik Hizmetleri Kavramlarının Araştırılması
}

\begin{tabular}{|c|c|}
\hline \multicolumn{2}{|c|}{ Suna Arslan ${ }^{1}$} \\
\hline Makale Bilgisi & $\ddot{O} z$ \\
\hline DOI: $10.21612 /$ yader.2015.013 & \multirow{3}{*}{ 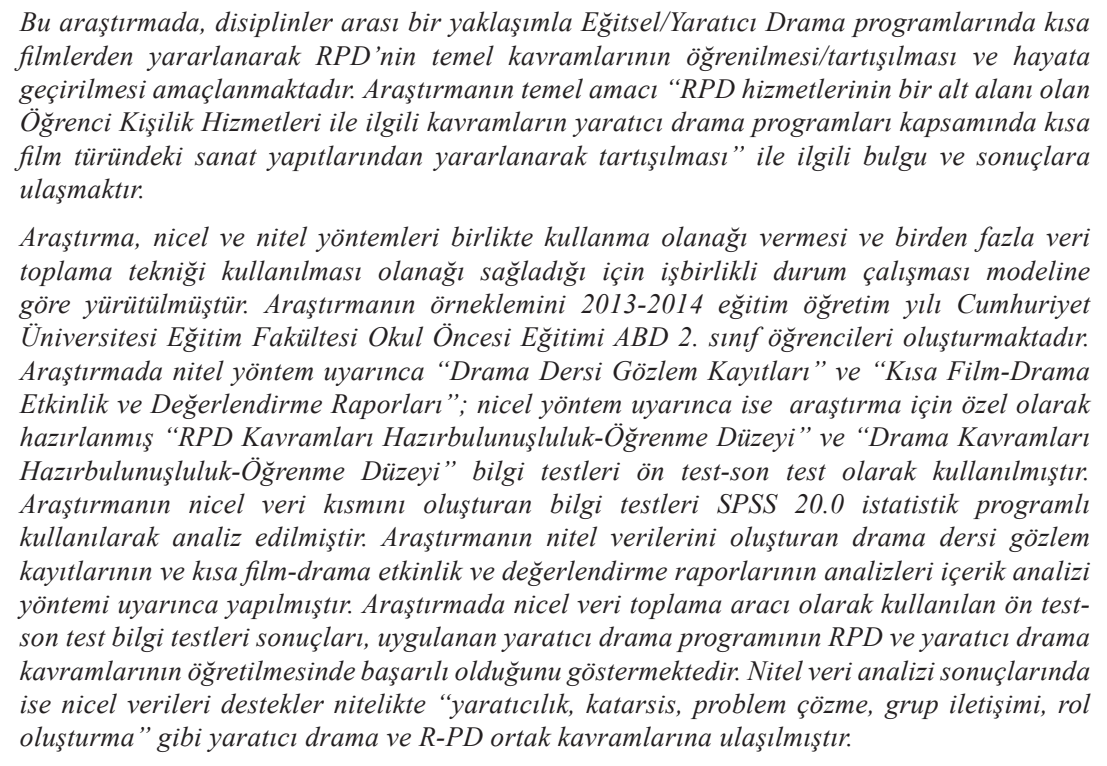 } \\
\hline $\begin{array}{l}\text { Anahtar Sözcükler } \\
\text { Yaratıcı drama } \\
R P D \\
\text { OKH } \\
\text { Grup ilişkileri }\end{array}$ & \\
\hline Klsa film & \\
\hline & $\begin{array}{l}\text { Araştırma sonucunda Ö̆grenci Kişilik Hizmetleri kavramlarının kısa film türündeki sanat } \\
\text { yapttarından yararlanılarak oluşturulan Yaratıcı Drama Programları aracılı̆g ile } \\
\text { sezdirilebileceği sonucuna ulaşılmıştır. }\end{array}$ \\
\hline
\end{tabular}

\section{Drama and Dramatization of Short Films Have Been İnvestigated by Means of the Concept of Student Personnel Services}

\begin{tabular}{l} 
Article Info \\
\hline DOI: 10.21612 yader.2015.013 \\
\hline Keywords \\
Creative drama \\
RPD \\
OKH \\
Short movie \\
Group relations
\end{tabular}

\begin{abstract}
This research aims to learning, discussing and puting into practice the basic consepts of RPD by aproaching diciplines interlude with the help of short movies in pedagogical/creative drama programs. The prime answer that this study looks for is "Discussing the concepts about one of the subcategory of RPD which is Student Individuality Service by utilize the art work of short movies in the extent of creative drama programs" finding results and reaching diagnoses.
\end{abstract}




\begin{abstract}
This research leaded by the cooperative situation performance model seeing it provides using multiple data capture technique and gives opportunity to use qualitative and quantitative methods together.The Enviornment of this research is teachers, teacher candidates and illustration contains Cumhuriyet Universty 2013 2014 Academic year Spring Term Education Department Pre School Education USA 2.Grade Students.In accardance with qualititative methd 'Drama lesson observation records" and 'shor movie-drama event and evaluation reports". In accordance to quantitative method specifically prepared 'RPD Concepts Presentable-Learning Level" and "Drama Concepts Presentable-Learning Level"pre test-final test and knowladge tests are used.Knowladge tests form the quantitave data of this research analized by using SPSS 20.0 statistic program.Anlysis of drama lesson observation records,short movie-drama events and evalution reports made based on content anlysis method which forms qualitative part of this research.Comparing to quantative data capture tool which are pre test-final test and knowladge tests results, the creative drama method used in this research succeed to teach RPD and Creative Drama concepts.Qualitative data anlysis results give countenance to quantitative datas and shows creativity, catharsis,problem solving,group communication,creating role and such concepts reached. According to research results Student Individuality Service concepts can be percieved by using Creative Drama Programs which created benefit from short movie genre artworks.
\end{abstract}

\title{
Giriș
}

Drama, "İçinde eylem olan, bir ya da birden çok insanın birbirleriyle, doğayla ya da başka nesnelerle etkileşerek yaşadıkları içsel ve dışsal devinimler ve onların yaşam durumlarını geniş ölçüde içeren etkinlikler" (Adıgüzel, 2013, s.1) olarak tanımlanabilir. Güzel Sanatlar ve Sosyal Bilimlerin farklı alanlarında da işlevsel bir yöntem olan drama, çağdaş eğitim anlayışıyla, Eğitsel Drama/Yaratıcı Drama programlarında daha çoklu kazanımları amaçlamaktadır. "Eğitimde sözel ve sayısal becerilerin geliştirilmesinin yanı sıra; duyumsal, sezgisel, görüsel, imgelemsel yaşantı ve deneyimlerin yer alması, duyusal ve duygusal süreçlere yer verilmesi gereklidir. Yaratıcı birey, çevre ve dünyasını, biçim ve mekân ilişkileri ve çok yönlü etkileşimler içinde görüp algılayabilendir”' (San, 1996, s.149).

Adıgüzel (2013) yaratıcılığın; kalıpların dışına çıkma, ana yoldan ayrılma, üretici düşünme, rahatsız edici durumları ve eksiklikleri hissedip doldurma, varsayımlar kurma ve gerektiğinde eskiyi değiştirme gibi özelliklere sahip olduğunu belirtmektedir. Yaratıcı dramanın sonuçtan çok sürece dayalı olduğu, drama ortamlarında katılımcıların karşılaştıkları sorunları çözmede birbirlerinin birikimlerinden faydalandıkları, sorunlara farklı çözüm yolları bulmayı öğrendikleri ve özgür düşünebilmeyi öğrenebildikleri görüşündedir.

Üstündağ (2001) yaratıcılığ1; daha önceden kurulmamış ilişkiler arasındaki bağlantıları kurabilme, yeni düşünce şeması ve farklı düşünceler ortaya koyabilme olarak ifade etmiştir. Yaratıcı dramayı ise, "Bir öğretim yöntemi, sanat eğitimi alanı ve bir disiplin olarak bireylerin kendini rahatça ifade edebildikleri, yaratıcı, grup çalışmalarına açık kişiler olmalarını sağlayan bir yaklaşım" (Üstündağ, 2002, s.140) olarak ifade etmiştir. San (1990) yaratıcı dramayı, önceden yazılmış bir metin olmadan katılımcıların kendi yaratıcı buluşları, eylemleri, özgün düşünce ve fikirleri ile oluşturdukları doğaçlama ve canlandırmalar olarak tanımlamaktadır.

Drama, eğitim ve öğretimde yeni bir oluşumdur. Ezbere dayalı bir eğitim, çocuğun zihinsel gelişimini, araştırmasını, paylaşmayı öğrenmesini engeller. Yaratıcı Drama alanında yeni/güncel yönelimlerden biri müze eğitimi ve drama konusundadır (Çakır İlhan ve Okvuran, 2001). Müzede 
drama, birçok duyu organının kullanılmasına olanak sağladığı gibi kişilik gelişimi üzerinde de önemli etkilere sahiptir. Gelişim süreçlerinde önemli olan birçok davranışın tanınmasına ve geliştirilmesine katkı sağlayan drama, "çocuk ve gençlerde en çok sorumluluk duygusu, iç disiplin, farklı ve yaratıcı düşünme, sözel ifade, grupla iletişim ve etkileşim, içgörü, değerleri kavrama, yapıcı eleştiride bulunma, kendini ifade ve kendi bakış açısını yansıtabilmeyi sağlar”' (Okvuran, 2001, s.19).

Drama, çocuğu geliştiren ve yetiştiren başlı başına bir eğitim alanı olup yaratıcılı̆̆ 1 geliştiren etkili bir yöntemdir. San’a göre (1996) drama; doğaçlama, rol oynama vb. tiyatro tekniklerinden yararlanılarak bir grup çalışması içinde katılımcıların, bir yaşantıyı, bir olayı, bir fikri, kimi zaman bir soyut kavramı ya da bir davranışı, kişinin bilişsel örüntülerinin yeniden düzenlendiği "oyunsu" süreçlerde anlamlandırılması ve canlandırılmasıdır. Bu tanımdan yola çıkılarak kısa filmlerin sanatsal gücü, etkili anlatımı, konu çeşitliliğine sahip olması ve zaman açısından kullanışlı olması, hem drama hem de Rehberlik-Öğrenci Kişilik Hizmetleri alanlarında yararlanılabilecek etkili bir eğitim aracı olarak düşünülmesini sağlamıştır.

Okulda öğrenciyi tanıma, anlama ve öğrencinin gelişmesine, büyümesine yardım eden psikometrik ölçme araçlarının uygulanması, mediko-sosyal yardımların sağlanması, eğitsel, kişisel, duygusal ve mesleksel rehberlik hizmetleri genellikle Öğrenci Kişilik Hizmetleri (ÖKH) terimi ile anılmaktadır (Özoğlu, 1992). Her öğrencinin kendine özgü bir kişilik yapısı vardır. Öğrencide istenmeyen davranışların önlenmesinde kişilik yapılarının bilinmesi gereklidir. Kişilik gelişimi bir bütün olmakla beraber, çeşitli yönlerden ele alınabilir. Fiziksel gelişim, zihinsel gelişim, duygusal gelişim, sosyal ve ahlaki gelişim kişilik gelişiminin birer yönüdür (Yavuzer, 1993). "Öğrenci kişilik hizmetleri, çağdaş eğitim anlayışının örgün eğitim etkinlikleri içine katmayı zorunlu gördüğü profesyonel bir hizmettir. Okul ortamında öğretim çalışmalarından ayrı bir şekilde, öğrencinin duygusal ve toplumsal yanlarını sağlıklı bir şekilde gelişmesini sağlayıcı etkinlikleri kapsar. ÖKH, eğitim öğretim faaliyetlerinden ayrı, fakat onlara paralel bir fonksiyon gösteren hizmetlerdir" (Yeşilyaprak, 2007, s. 4).

Yukarıdaki tanımlar, görüşler ve ÖKH kapsamına giren hizmetler gözönüne alındığında ÖKH'nin; öğrenci ihtiyaçlarını karşılamaya, öğrencinin gelişimsel görevlerini yerine getirmesine ve eğitim öğretim faaliyetlerini engelleyen öğrenci sorunlarını çözmeye yönelik olduğu görülmektedir. Başka deyişle öğrenciler ÖKH hizmetlerinden yeterli düzeyde yararlandığında başarıyı ve uyumu engelleyen sorunların en az düzeye indirgenebileceği ifade edilmektedir. ÖKH'nin bu amaçlarını gerçekleştirebilmesi için öğrenci merkezli, esnek, yaratıcılığı/doğaçlamayı ve grup ilişkilerini destekleyen hem fiziksel/mekânsal hem de sosyal ortamlara ihtiyacı vardır. Bu çalışmada bu koşulların yaratıc1 drama yöntemi ve ortamı aracılığıyla oluşturulması amaçlanmıştır. Öğrenci merkezli bir yöntem olduğu bilinen yaratıcı dramanın ÖKH konu ve kavramlarının tartışılması için uygun ortam sağlayacağı bu araştırmanın sayıltılarından biridir.

$\mathrm{Bu}$ araştırmanın ana amacı; RPD hizmetlerinin alt alanı olan Öğrenci Kişilik Hizmetleri ile ilgili kavramların, yaratıcı drama programları kapsamında kısa film türündeki sanat yapıtlarından yararlanarak tartışılması ile ilgili bulgu ve sonuçlara ulaşmaktır. Bu amaç doğrultusunda aşağıdaki araştırma sorularına cevap aranmıştır: 
1. Yaratıcı drama yöntem ve teknikleri RPD programlarının amaçlarına ulaşılmasında etkili bir yöntem midir?

2. Uygulanan yaratıcı drama programı sürecinde, drama ve RPD kavramları açısından hangi öğrenmeler gerçekleşmiştir?

3. Kısa filmler aracılı̆̆ıyla oluşturulan yaratıcı drama etkinliklerinde hangi RPD kavramlarına ilişkin farkındalık kazanılmıştır?

\section{Yöntem}

\section{Araştırmanın Modeli}

Araştırma deseni nitel ve nicel yöntemleri birlikte kullanma olanağı verecek şekilde oluşturulmuştur. Glesne (2013) yorumlayıcı paradigma yaklaşımı gereği nicel ve nitel yöntemlerin ya da tekniklerin birleştirilmesini önerir; ancak veri toplamada bu iki yöntemden birinin daha ağırlıklı kullanılabileceğini vurgular. Bu araştırmada da veri toplamada nicel ve nitel yöntemler birlikte kullanılmış ve yaratıcı dramanın doğasına uygun olarak nitel yöntemler ağırlıklı olarak yer almıştır. Bu araştırmada nitel yaklaşımın tercih edilme nedeni Yıldırım ve Şimşek (2005)'in belirttiği gibi, yöntemin bütüncül yaklaşımı ve doğal ortama duyarlı olması, katılımcıların algılarının ortaya konmasına uygun ortam hazırlamasıdır. Bu araştırmada nitel yöntem uyarınca drama dersi gözlem kayıtları, kısa film örnekleri ve kısa film-drama etkinlik ve değerlendirme raporları üzerinde doküman inceleme tekniği kullanılmıştır. Araştırmada nicel yöntem uyarınca bu araştırmanın sayısal verilerini toplamak üzere oluşturulan RPD ve Güzel Sanatlar Eğitimi (GSE) kavramları bilgi testleri kullanılmıştır.

\section{Örneklem/Çalışma Grubu}

$\mathrm{Bu}$ araştırmanın çalışma grubu açısından hedef evreni tüm öğretmenler ve öğretmen adaylarıdır. Ulaşılan çalışma grubu açısından örneklemi ise Cumhuriyet Üniversitesi Eğitim Fakültesi Okul Öncesi Ana Bilim Dalı’nda birinci ve ikinci öğretimde eğitim alan toplam 133 öğretmen adayından oluşmaktadır. Nitel yöntem uyarınca yaratıcı drama temelli RPD programı bu grupla birlikte drama dersi sürecinde uygulanmıştır.

\section{Veri Toplama Araçları}

$\mathrm{Bu}$ araştırmanın problemine dayalı olarak öncelikle kullanılan veri toplama araçları, ön testson test formunda bilgi testleridir. Bu bilgi testleri araştırmanın olgusal nitelikteki verilerini elde etmek için oluşturulmuştur. Bu yolla ulaşılan ve nesnel sağlamlığı olduğu düşünülen olgusal veriler araştırmanın nitel boyuttaki veri toplama araçları olan drama günlükleri ve kısa film/drama etkinlik raporları aracılığıyla elde edilen yargısal verilerle desteklenmiştir. Başka deyişle çalışmanın nesnel/ nicel boyutu öznel gerçeklere, yoruma dayalı bulgulara ulaşmayı sağlayacak olan ayrıntılı nitel verilerle desteklenmiştir. Kısa filmlerin drama dersleri ortamında ve ÖKH kavramları bağlamında izlenmesi, tartışılması ve bir drama etkinliği şeklinde oyunlaştırılmasıyla, farklı bakış açıları ve yorumlama çeşitliliğine ulaşılması amaçlanmaktadır. Kısa filmler gerçek yaşantıların/olayların yansımasıdır; bu yansımanın kısa filmler üzerinden kısa sürede ve etkili bir dille verilmesi araştırma sürecine avantaj sağlamıştır. 


\section{a. Drama Dersi Gözlem Kayıtları}

Araştırmanın gözleme dayalı verileri katılımcı-yapılandırılmamış gözlem türü uyarınca elde edilmiştir. Bu süreçte Cumhuriyet Üniversitesi Eğitim Fakültesi 2013-2014 Yaz Okulu programında Eğitsel Drama dersleri kapsamında, araştırmacı ve dört gönüllü öğrenci katılımcı gözlemci olarak dersleri izlemiş ve gözlem kayıt formları tutmuşlardır. Katılımcı gözlem türünün bu araştırmada seçilme nedeni; davranışın gerçekleştiği doğal ortamda yapılması, diğer metotlara göre doğal duruma uygunluğu, derinlemesine bilgi sağlaması ve bütüncül bir bakış açısına sahip olması gibi avantajlarıdır (Yıldırım ve Şimşek, 2005). Araştırmada yapılandırılmamış gözlem formları kullanılmış, gözlemciler gözlemledikleri bütün durumları ayrıntılı olarak kaydetmişlerdir. Bu yolla drama dersi günlüklerinde 8 haftalık süreç içerisinde uygulanan drama etkinlikleri ve katılımcı yorumları betimlenmiştir. Gözlem raporlarından oluşturulan bu günlükler içerik analizine tabi tutulmuş ve analiz sonucunda ulaşılan temalar tablolaştırılmış, GSE ve RPD alanları ile ilgili kavram listeleri elde edilmiştir.

\section{b. Bilgi Testi Uygulamaları}

Araştırma için hazırlanan Bilgi Testleri "Drama dersi gözlem kayıtları"na uygulanan içerik analizi sonuçlarında ulaşılan GSE ve RPD kavramlarından en çok yinelenim sayısına sahip olan kavramlar kullanılarak oluşturulmuştur. Başka deyişle bu kavramlara ilişkin bilgi testlerinin maddeleri ortaya çıkmış; bu yolla araştırmanın geçerliliğini ve güvenirliliği kazanılmıştır. Bir tür anket sayılabilecek olan Bilgi Testleri, öğrencilerin bu iki alandaki öğrenme düzeylerini ölçme amaçlıdır. Nicel analizler sonucu "Drama Kavramları Hazırbulunuşluluk-Öğrenme Düzeyi” için güvenirlik analizi sonucu \%97, "RPD Kavramları Hazırbulunuşluluk-Öğrenme Düzeyi” için güvenirlik analizi sonucu ise \%71 olarak tespit edimiştir. Soru kağıtlarını cevaplama süresi madde sayısı ve zorlukları ile doğru orantılı olarak 35 dakika şeklinde belirlenmiştir. Hazırlanan bilgi testleri drama programının başında ve sonunda ön test-son test şeklinde uygulanmıştır.

\section{c. Kısa Film-Drama Etkinlik ve Değerlendirme Raporları}

Araştırma deseninde ilk adımı oluşturan drama dersi gözlem kayıtlarının içerik analizinden elde edilen sonuçlara göre araştırma kapsamında yer alan RPD-ÖKH kavramları saptanmıştır. İçerik analizi sonuçlarına göre yinelenim sıklığı en fazla olan dört kavram yaratıcı drama yöntemi uyarınca tartışılmıştır. Bu kavramlar; yaratıcılık/doğaçlama, grup ilişkileri/iletişimi, problemin farkına varma/ problem çözme, rahatlama/katarsistir. Ayrıca bu kavramların ÖKH içeriğinde yer aldığı görülmüştür. Yerli-yabancı kısa film örnekleminden eğitsel rehberlik ve ÖKH kavramlarını dolaylı veya doğrudan içeren kısa film seçkisi oluşturulmuştur. Bu kısa filmler, öğretmen adayları gruplarınca izlenmiş ve tartışılmıştır. Gerçek yaşantıların kurgusal yansımaları olan kısa filmlerin grupca izlenmesi ve yorumlanması ile senaristin kısa filme katabileceği öznel yargıların en aza indirgenebileceği düşünülmektedir.

RPD kavramlarını içeren bir kısa filmi kendi isteklerine göre seçip izleyen, drama yöntemiyle oyunlaştıran ve sunumunu yapan katılımcı grupların çalışmaları izlenmiş ve grupların 10 düzeyde drama değerlendirme ölçütüne göre yazdıkları etkinlik değerlendirme raporları incelenmiştir. $\mathrm{Bu}$ ölçütler bu araştırma kapsamında kullanılmak üzere özel olarak oluşturulmuştur ve şu maddeleri içermektedir: "Ĕ̆itsel, ĕglenme/katarsis, yaratıcılık/doğaçlama, grup uyumu/işbirliği, konu/kavram seçimi, araç gereç kullanma/geliştirme, müzik uyarlama, tempo/zamanı iyi kullanma, etik ve estetik düzeyleri". Kısa film-drama etkinlik ve değerlendirme raporları, araştırmanın ilk adımını oluşturan 
yaratıcı drama ve RPD kavramlarının ilişkisinin saptanmaya çalışıldığı drama günlükleri benzeri bir doküman elde etme ve inceleme olană̆ını araştırmacıya sağlamıştır.

Bu raporların içerik analizi sonucu ortaya çıkan RPD-ÖKH kavramlarının yinelenim sıklığına göre sıralaması tablolar şeklinde gösterilmiştir. Başka bir deyişle kısa filmin izlenmesi, filmin özgün içeriğinin yorumlanması ve drama gruplarının kendi kurguladıkları konu ve kavramların hangi RPD kavramları ile buluştuğu araştırmacı tarafından tespit edilmeye çalışılmıştır.

\section{Verilerin Çözümlenmesi}

Araştırmanın nicel veri kısmını oluşturan bilgi testleri SPSS (Statistical Package for The Social Science) 20.0 paket programı kullanılarak analiz edilmiştir. Bütün testler $\mathrm{p}<0.05$ anlam düzeyinde incelenmiştir. Her bir hipotezin test edilmesi için farklı yöntemler kullanılmıştır. Bilgi testlerinin güvenilirliğini test etmek amacıyla Cronbach Alpha değerinden ve geçerliliğini sınamak için ise Kaiser-Meyer-Olkin istatistiğinden yararlanılmıştır. Anket sonucu elde edilen veriler parametrik test koşullarını sağlayanlar için t-Testi'nden, parametrik olmayanlar için Wilcoxon $\mathrm{T}$ Testi, Kruskal Wallis H Testi ve Varyans Analizi’nden faydalanılmıştır. Analizler sonucunda ulaşılan sonuçlar tablolar halinde verilmiştir. Araştırmanın nitel verilerini oluşturan drama dersi gözlem kayıtlarının ve kısa film-drama etkinlik ve değerlendirme raporlarının analizleri ise içerik analizi yöntemi esas alınarak yapılmıştır. Analizler sonucunda ulaşılan sonuçlar tablolar halinde verilmiştir.

\section{Bulgular}

\section{Yaratıcı Drama Kavramlarını Öğrenme Düzeyi ile İlgili Bulgular ve Yorumlar}

Araştırma verilerinin normal dağılıma uygun olup olmadığını ortaya koymak amacıyla ön test-son test bilgi testi verilerine Kolmogorow-Smirnov testi ve normallik varsayımını sınayan en güçlü test olarak bilinen Shapiro-Wilk testi uygulanmıştır.

Tablo 1. Drama Kavramları Öğrenme Düzeyi Ön Test ve Son Test Ortalama Puanlarının t-Testi Sonuçları

\begin{tabular}{ccccccc}
\hline Ölçüm & $\mathrm{N}$ & $\overline{\mathrm{X}}$ & $\mathrm{S}$ & $\mathrm{sd}$ & $\mathrm{t}$ & $\mathrm{p}$ \\
\hline Öntest & 133 & 1,193 & 0,073 & 132 & 10,363 & 0,000 \\
Sontest & 133 & 1,332 & 0,131 & & & \\
\hline
\end{tabular}

Tablo 1'de öğrencilerin yaratıcı drama dersini almadan önce ve aldıktan sonra yaratıcı drama kavramlarını öğrenme ve uygulama düzeylerinde anlamlı bir farklılık gösterip göstermediğine ilişkin t-testi sonuçları verilmiştir. Analiz sonucu $\mathrm{P}<0.05$ olarak tespit edilmiştir. Bu bulgu ön test-son test puanları arasında anlamlı bir fark olduğunu ve uygulanan programın başarılı olduğunu göstermektedir.

Bu bulgular araştırmanın ön çalışmasını oluşturan drama gözlem raporları bulguları ve drama etkinlik raporları ile uyumludur. Daha açık ifade ile drama uygulamalarında kısa filmler aracılığıyla farkındalık yaratılmak istenilen kavramlar olan yaratıcılık/doğaçlama, problem çözme, grup iletişimi, katarsis kavramlarında anlamlı öğrenme düzeyine ulaşıldığı görülmektedir. 


\section{RPD Kavramları Öğrenme Düzeyi ile İlgili Bulgular ve Yorumlar}

Araştırma verilerinin normal dağılıma uygun olup olmadığını ortaya koymak amacıyla ön test-son test bilgi testi verilerine Kolmogorow-Smirnov testi ve normallik varsayımını sinayan en güçlü test olarak bilinen Shapiro-Wilk testi uygulanmıştır.

Tablo 2. RPD Kavramları Öğrenme Düzeyi Ön Test ve Son Test Ortalama Puanlarının t-Testi Sonuçları

\begin{tabular}{ccccccc}
\hline Ölçüm & $\mathrm{N}$ & $\overline{\mathrm{X}}$ & $\mathrm{S}$ & $\mathrm{sd}$ & $\mathrm{t}$ & $\mathrm{p}$ \\
\hline Öntest & 99 & 13,494 & 4,061 & 98 & $-11,855$ & 0,000 \\
Sontest & 99 & 20,171 & 3,020 & & & \\
\hline
\end{tabular}

Tablo 2'de öğrencilerin yaratıcı drama dersini almadan önce ve aldıktan sonra RPD kavramlarını öğrenme ve uygulama düzeylerinde anlamlı bir farklılık gösterip göstermediğine ilişkin t-testi sonuçları verilmiştir. Analiz sonuçları ön test-son test puanları arasında anlamlı bir fark olduğunu göstermektedir. Bu bulgu uygulanan programın başarılı olduğunu göstermektedir. Uygulanan ön test-son test bilgi testi RPD alanı ile ilgili olarak bu alanın içerdiği kavramlar daha ağırlıklı olarak düzenlenmiştir. Drama programı bağlamında izlenen kısa filmler aracılığıyla, RPD kavramları öğrenme düzeyinin yüksek çıkması bu amaçla uyumlu bir bulgudur.

\section{Drama Uygulamaları Etkinlik Raporları ile İlgili Bulgular ve Yorumlar}

Araştırmanın nitel veri aracını oluşturan etkinlik raporlarını yazan gruplar kısa filmleri kendileri seçip izlemiş, yaratıcı drama yöntemi kullanarak filmi dramaya uyarlamış, tartışma ve değerlendirme çalışmaların 10 değerlendirme ölçütüne göre yapmıştır. Grupların raporlaştırdıkları etkinlikler içerik analizi yöntemi ile incelenmiştir.

Tablo 3. Kisa Filmlerden Uyarlanan-Yaratıcı Drama Etkinliklerinin Değerlendirme Raporlarının İçerik Analizi Sonuçları (Temalar, Yinelenim Toplamları)

\section{Tüm Grupların Drama Etkinlikleri Ortak Temalarının Frekans Sıklığına Göre Sıralanması}

\begin{tabular}{lll}
\hline 1. & Grup iletişimi/işbirliği & $330(\% 22,43)$ \\
\hline 2. & Yaratıcılık/doğaçlama & $267(\% 18,15)$ \\
\hline 3. & Rol oluşturma/oynama & $224(\% 15,22)$ \\
\hline 4. & Katarsis/rahatlama & $214(\% 14,54)$ \\
5. & Eğitsel/öğretici & $165(\% 11,21)$ \\
\hline 6. & Çatı̧ma/problem çözme & $119(\% 8,08)$ \\
\hline 7. & Müzik uyarlama & $90(\% 6,11)$ \\
8. & RPD ortamı & $62(\% 4,21)$ \\
\hline
\end{tabular}

Tabloda, 17 drama grubunun kısa film izleme, film içeriğini yaratıcı dramaya uyarlama ve etkinlik değerlendirme raporlarının içerik analizi sonuçları görülmektedir. İçerik analizi sonuçlarıyla ulaşılan temalar, yaratıcı drama ve R-ÖKH kavramlarıyla ilişkilendirilerek adlandırılmış ve yinelenim 
sıklıklarına göre sıralanmıştır. Temaların yinelenim sayıları ve yüzdelik değerleri belirtilmiştir. "Tüm Gruplar için-Kısa filmlerin ortak kavramsal temalarının yinelenim sayısına göre sıralanması" Tablo 3’ün son sütunünda gösterilmiştir. Bu hücredeki sonuçlar kısa film kullanılarak uygulanan yaratıcı drama programında R-ÖKH kavramlarının tartışılabileceğini göstermektedir.

\section{Drama Gözlem Raporları ile İlgili Bulgu ve Yorumlar}

Tablo 4. Drama Dersi Gözlem Kayıtları İçerik Analizi İle Ulaşılan Görüşler-Temalar

\begin{tabular}{|c|c|c|c|c|}
\hline \multicolumn{5}{|c|}{$\begin{array}{c}\text { Drama Dersi Gözlem Kayıtları İçerik Analizi İle Ulaşılan Görüşler-Temalar } \\
\text { (Temalar ve Yinelenim Sayıları) }\end{array}$} \\
\hline $\begin{array}{l}\text { Drama Alanı/ } \\
\text { Kavramları ile İlgili } \\
\text { Mesajlar \%30,50 }\end{array}$ & $\begin{array}{l}\text { Rpd Alanı / } \\
\text { Kavramları ile } \\
\text { İlgili Mesajlar } \\
\% 28,38\end{array}$ & $\begin{array}{l}\text { Drama Grubu } \\
\text { ile İlgili Mesajlar } \\
\% 19,49\end{array}$ & $\begin{array}{l}\text { Etkili İletişim } \\
\text { ile İlgili } \\
\text { Mesajlar } \\
\text { \%11,01 }\end{array}$ & $\begin{array}{l}\text { Diğer Başlıklar } \\
\text { ile İlgili Mesajlar } \\
\text { \%10,59 }\end{array}$ \\
\hline $\begin{array}{l}\text { 1.Yaratıcılık/doğaçlama } \\
\text { (45) }\end{array}$ & $\begin{array}{l}\text { 1.Problemin farkına } \\
\text { var/problem çözme } \\
\text { (16) }\end{array}$ & $\begin{array}{l}\text { 1.Grup uyumu/ } \\
\text { işbirliği (35) }\end{array}$ & $\begin{array}{l}\text { 1.İletişim } \\
\text { becerisi/etkili } \\
\text { iletişim (12) }\end{array}$ & $\begin{array}{l}\text { 1.Örtülü öğrenme } \\
\text { (kartopu etkisi) } \\
(10)\end{array}$ \\
\hline $\begin{array}{l}\text { 2.Özgür bir ortam/ } \\
\text { yargilanmadan } \\
\text { davranabilme (10) }\end{array}$ & 2.Rahatlama (13) & $\begin{array}{l}\text { 2.Isınma/ } \\
\text { kaynaşma } \\
\text { çalışmaları (9) }\end{array}$ & $\begin{array}{l}\text { 2.Kendini ifade- } \\
\text { vucüt dili (10) }\end{array}$ & $\begin{array}{l}\text { 2.Drama mekanı } \\
\text { (6) }\end{array}$ \\
\hline $\begin{array}{l}\text { 3.Eğitim sistemi } \\
\text { eleştirisi/dramayla geç } \\
\text { tanışma (6) }\end{array}$ & 3.Empati (11) & $\begin{array}{l}\text { 3.Başkalarını } \\
\text { tanıma (1) }\end{array}$ & 3. Rahat olma (4) & $\begin{array}{l}\text { 3.Drama kiyafetleri } \\
\text { (4) }\end{array}$ \\
\hline $\begin{array}{l}\text { 4.Olaylara farklı } \\
\text { açılardan bakabilme (5) }\end{array}$ & $\begin{array}{l}\text { 4.Kendini tanıma, } \\
\text { yeteneğini } \\
\text { farketme/ geliştirme } \\
\text { (11) }\end{array}$ & $\begin{array}{l}\text { 4.Toplum içinde } \\
\text { kabul görme (1) }\end{array}$ & & 4.Drama lideri(4) \\
\hline $\begin{array}{l}\text { 5.Drama planlama/ } \\
\text { uygulama ( } 2 \text { ) }\end{array}$ & 5.Özgüven (6) & & & $\begin{array}{l}\text { 5.Drama müzikleri } \\
\text { (1) }\end{array}$ \\
\hline 6.Esnek olma (2) & $\begin{array}{l}\text { 6.Hayatın } \\
\text { zorluklarına karşı } \\
\text { hazırbulunuşluluk } \\
\text { (3) }\end{array}$ & & & \\
\hline $\begin{array}{l}\text { 7.İnsanın en doğal hali } \\
\text { (1) }\end{array}$ & 7.İyi olma hali (3) & & & \\
\hline 8.Absürtlük (1) & $\begin{array}{l}\text { 8.Kendini açma (2) } \\
\text { 9.Günlük hayattan } \\
\text { sıyrılma (2) } \\
\text { 10.Heyecan (1) }\end{array}$ & & & \\
\hline $\mathrm{T}: 72$ & $\mathrm{~T}: 67$ & $\mathrm{~T}: 46$ & $\mathrm{~T}: 26$ & $\mathrm{~T}: 25$ \\
\hline$\% 30,50$ & $\% 28,38$ & $\% 19,49$ & $\% 11,01$ & $\% 10,59$ \\
\hline Toplam Yinelenim : 236 & & & & \\
\hline
\end{tabular}


Drama dersi gözlem kayıtlarının içerik analizi sonuçları nicel ve nitel verileri destekler şekilde birinci sırada "Drama alanı/kavramları ile ilgili mesajlar" (\%30,50); ikinci sırada ise "RPD alanı/kavramları ile ilgili mesajlar" $(\% 28,38)$ olarak saptanmıştır. Bu bulgular araştırma sorusunda bulunan drama etkinlikleri ile RPD kavramlarının tartışılabileceğini destekler niteliktedir.

\section{Sonuç ve Öneriler}

Araştırmanın nicel ve nitel veri toplama araçlarından elde edilen sonuçlar araştırma soruları kapsamında ele alınmıştır.

"Yaratıcı drama yöntem ve teknikleri RPD programlarının amaçlarına ulaşılmasında etkili bir yöntem midir?” araştırma sorusuna ilişkin sonuçlar

Öğretmen adaylarının yaratıcı drama temelli RPD etkinlik programı başında ve sonunda uygulanan "Drama kavramları hazırbulunuşluluk-öğrenme düzeyi" ve "RPD kavramları hazırbulunuşluluk-öğrenme düzeyi” bilgi testlerinden aldıkları öntest ve sontest puanları arasında anlamlı bir farklılık olup olmadığını belirlemek amacıyla t testi yapılmıştır. Analiz sonucu $\mathrm{P}<0.05$ olarak tespit edilmiştir. Bu bulgu, ön test-son test puanları arasında anlamlı bir fark olduğunu ve uygulanan programın RPD programlarının amaçlarına ulaşılmasında etkili bir yöntem olduğunu göstermektedir.

"Uygulanan yaratıcı drama programı sürecinde, drama ve RPD kavramları açısından hangi öğrenmeler gerçekleşmiştir?” araştırma sorusuna ilişkin sonuçlar

Araştırmada nitel veri toplama araçları olarak kullanılan "Drama dersi gözlem kayıtları" ve "Kısa film-drama etkinlik ve değerlendirme raporları"na uygulanan içerik analizi sonuçlarına ulaşılan "yaratıcılık, katarsis, problem çözme, grup iletişimi, rol oluşturma" gibi kavramlara ulaşılması uygulanan programın etkililiğini göstermektedir.

"Kısa filmler aracılığıyla oluşturulan yaratıcı drama etkinliklerinde hangi RPD kavramlarına ilişkin farkındalık kazanılmıştır?” araştırma sorusuna ilişkin sonuçlar

Araştırmanın nitel veri toplama araçlarından biri olan "Kısa film-drama etkinlik ve değerlendirme raporları"na ilişkin içerik analizi sonuçlarında ortaya çıkan "Grup iletişimi, yaratıcılık/doğaçlama, rol oluşturma/oynama, katarsis/rahatlama, eğitsel/öğretici, çatışma/problem çözme, müzik uyarlama ve RPD ortamı” temaları, uygulanan programın RPD kavramlarına ilişkin farkındalık kazandırdığını göstermektedir.

\section{Kaynakça}

Adıgüzel, Ö. (2013). Eğitimde yaratıcı drama. Ankara: Pegem.

Adıgüzel, Ö. (2006). Yaratıcı drama kavramı, bileşenleri ve aşamaları. Ankara Üniversitesi, Yaratıcı Drama Dergisi, 1(1), 22.

Glesne, C. (2013). Nitel Araştırmaya Giriş (Çev. Ersoy,A., Yalçınoğlu,P.). Ankara: Anı Yayıncılık.

Okvuran, A. (2001). Drama öğretmeninin yetişim sorunsalı. Öğretmen Dünyası Aylık Meslek Dergisi, 8-19.

Özoğlu, S.Ç. (1992). Davranış bilimlerinde anket; Bilgi toplama araçlarının geliştirilmesi. Ankara Üniversitesi Eğitim Bilimleri Fakültesi Dergisi, 25 (2), 321-337.

San, İ. (1990). Eğitimde yaratıı drama. Ankara Üniversitesi Eğitim Bilimleri Fakültesi Dergisi, 23 (2), 573 582.

San, İ. (1996). Yaratıcılığı geliştiren bir yöntem ve yaratıcı bireyi yetiştiren bir disiplin -eğitsel yaratıcı drama. Yeni Türkiye Dergisi, Eğitim Özel Saylsı, Ocak-Şubat, Sayı 7, 149.

Tan, H. (2000). Psikolojik danışma ve rehberlik teori ve uygulama. Ankara: MEB Yayınları 
Üstündağ, T. (2001). Yaratıcı drama öğretmenimin günlüğ̈̈. Ankara: PegemA Yayınları.

Üstündağ, T. (2002). Yaratıcllı̆̆a yolculuk. Ankara: Pegem Yayınları.

Yavuzer, H. (1993). Çocuk psikolojisi. (9. bs.) İstanbul: Remzi Kitabevi.

Yıldırım, A. ve Şimşek, H. (2005). Sosyal bilimlerde nitel arastirma yöntemleri. Seçkin Yayıncılık.

Çakır, İ. A. ve Okvuran, A. (2001). Bir eğitim ortamı olarak müze ve müze çalışmaları. Anadolu Sanat Dergisi, 11, 87-93. https://earsiv.anadolu.edu.tr/xmlui/bitstream/handle/11421/937/172606.pdf?sequence=1\&isAllowed $=\mathrm{y}$ 